\title{
Manager's Discretionary Power and Comparability of Financial Reports: An Analysis of the Regulatory Transition Process in Brazilian Accounting*
}

\author{
Alex Mussoi Ribeiro \\ Universidade Federal de Santa Catarina, Centro Socioeconômico, Departamento de Ciências Contábeis, Florianópolis, SC, Brazil \\ Carlos Henrique Silva do Carmo \\ Universidade Federal de Goiás, Faculdade de Administração, Ciências Contábeis e Economia, Departamento de Ciências Contábeis, Goiânia, GO, Brazil \\ Luiz Paulo Lopes Fávero \\ Universidade de São Paulo, Faculdade-de Economia, Administração e Contabilidade, Departamento de Contabilidade e Atuária, São Paulo, SP, Brazil
}

L. Nelson Carvalho

Universidade de São Paulo, Faculdade de Economia, Administração e Contabilidade, Departamento de Contabilidade e Atuária, São Paulo, SP, Brazil

Received on 04.17.2015 - Desk acceptance on 06.19.2015 - $3^{\text {rd }}$ version approved on 12.21.2015.

\section{ABSTRACT}

This research aimed to directly evaluate the impact of the accounting regulatory flexibility movement on the comparability of financial reports. The country chosen for the analysis was Brazil, because it was one of the few countries in the world where a process of regulatory. change from a completely rule-based standard with a strong link to tax accounting (Lopes, 2011) to a principle-based standard with greater need for decision by managers who prepare the financial reports took place. To measure comparability, the accounting function similarity model developed by DeFranco, Kothari and Verdi (2011) was used. The companies analyzed were all listed ones with full data for the period concerned having, at least, a pair company within the same economic activity sector. To obtain the research results, we adopted a panel data model where the years 2005 to 2012 were compared to the year 2004 . The results obtained prove that, on average, there was no significant decrease in the comparability level within country during the regulatory transition period in Brazil. On the contrary, there was an increase in genuine comparability in the year 2012 when compared to 2004. In the model adjusted by stepwise, the years 2011 and 2012 had a significantly higher average comparability when compared to 2004. The results found corroborate other researches addressing the quality of accounting information (Collins, Pasewark, \& Riley, 2012; Psaros \& Trotman, 2004; Agoglia, Doupnik, \& Tsakumis, 2011) and prove the superiority of the principle-based standard also over the comparability of financial reports. The main conclusion of this research is that increasing manager's discretionary power through flexibility of accounting standards does not decrease the comparability of financial reports.

Keywords: comparability, regulation, International Financial Reporting Standards, principles, rules. 


\section{INTRODUCTION}

The corporate scandals that occurred in the beginning of the last decade (e.g. Enron and WorldCom) and the subprime crisis in the USA rekindled an old debate between accountants on how accounting should be regulated: according to rather strict and specific rules or rather flexible and generic principles - for more details see Merino and Coe (1978).

According to the Securities and Exchange Commission (SEC) (2003), accounting standards may be generally divided into two types: those based on rules and those based on principles. According to the entity, those based on principles are typically characterized by a content rather aimed at the intentions instead of the actions, i.e. there are general guidelines, but no detailed implementation guide. In turn, the standards based on rules have a certain level of detail concerning their implementation and greater compliance. Regarding this theme, Collins, Pasewark and Riley (2012) claim that, according to this characterization, for a given scenario of financial reporting, standards based on principles require from a professional accountant greater judgment, while those standards based on rules requiring greater expertise in seeking legislative knowledge. Researchers claim that most accounting standards - either the U.S. or the International Financial Reporting Standards (IFRS) - have an extension based on rules, i.e. they contain rules that a certain entity must follow to report specific transactions. However, they may vary in the specificity degree (bright lines), where the more specific (smaller space for judgment) are those based on rules and the less specific (larger space for judgment) are those based on principles.

In the discussion between rules and principles there are arguments for both sides. Those who support principles claim they improve quality in the information environment and not necessarily increase variability in the accounting outcomes (Silva, 2013; Agoglia, Doupnik, \& Tsakumis, 2011; Donelson, McInnis, \& Mergenthaler, 2012; Jamal \& Tan, 2010; Mergenthaler, 2009; Stolowy \& Ding, 2003; Psaros \& Trotman, 2004; Iatridis, 2010). Those supporting rules point out the contrary: that without the latter, there is no comparability and managers might be susceptible to greater manipulation of outcomes (Sunder, 2009; Schipper, 2003; D’Arcy, 2000). As noticeable in both arguments, the discussion revolves around the comparability of financial reports. By adopting the IFRS around the world, many countries (e.g. Brazil, Germany, and China) have undergone a change from their rather specific rule-based accounting standards, often linked to tax issues, to principle-based standards - such as the IFRS (Tweedie, 2007) - and perhaps the main justification in a large part of the countries that decided to adopt the IFRS is increasing comparability between different countries.

Although there is a real relationship between comparability and accounting regulation, little is known about the behavior of the latter (Ball, 2006; Madsen, 2011). In the case of adopting international standards, the gain in comparability between companies from different countries is due to using a single standard and it is already expected, because there is a convergence of regulation that restricts accounting choices by managers and auditors within the same spectrum. On the other hand, the gain in comparability between companies from different countries may have generated a decrease in comparability between companies from the same country that had already adopted a single accounting standard, often more restrictive in accounting choices when compared to the international standards. On this regard, a technical study conducted by the Foundation Institute for Accounting, Actuarial, and Financial Research (FIPECAFI) and Ernst \& Young (2013, p. 7) highlights, in the Brazilian context, that "the way how some IFRS are applied has not become a consensus among market participants, yet, something which raises doubts about comparability of financial statements."

In the academy there is also no consensus about the role of regulation concerning comparability (Cole, Branson, \& Breesch, 2012). On the one hand, some authors argue that the standards based on principles increase the level of judgment and the diversity of interpretations of accounting phenomena, thus they can decrease the consistency and comparability of financial reports (Sunder, 2009; Schipper, 2003; D’Arcy, 2000). On the other hand, certain authors argue just the opposite, i.e. an increased level of judgment allows managers to incorporate more properly the economic events and their various nuances in accounting numbers, thus increasing their comparability (Dye \& Verrecchia, 1995; Securities and Exchange Commission, 2003; Agoglia et al., 2011). The studies by Collins et al. (2012) and Agoglia et al. (2011) found differences between accounting choices (and, as a consequence, in the final outcome of financial reports) by managers working under rather strict regulatory systems when compared to those working under rather flexible systems, although in the latter no rather scattered outcomes have been found. In turn, Dye and Verrecchia (1995) argue, based on their research, that a pattern with greater discretion is more informative than a strict pattern. However, such flexibility can increase opportunistic management of outcomes by preparers of financial statements.

Although there are empirical studies that evaluated the effects of regulatory changes on outcomes of financial reports or on the interpretive behavior of a manager in translating economic events into accounting numbers (Agoglia et al., 2011; Collins et al., 2012; Dye, 1985; Dye \& Verrecchia, 1995; Psaros \& Trotman, 2004; Stolowy \& Ding, 2003; Ashbaugh, 2001; Ashbaugh \& Pincus, 2001; Nelson, 2003; Jamal \& Tan, 2010; Donelson et al., 2012), there is little prior evidence of the impact of regulatory flexibility directly on the comparability of financial re- 
ports. As this information feature is linked to quality of the information environment that, in turn, may affect proper functioning of the economy and the relationship between regulation and comparability has not been well established, yet, there emerges the guiding question of this paper: Which is the effect of regulatory flexibility on the comparability of financial reports?

This is a critical issue both in the domain of the adoption of international standards and outside it. This paper, in general, may help pointing out the impact of a standard based on rules or principles concerning comparability that, according to Schipper (2003) and Kothari, Ramanna and Skinner (2010), is the very driving force through which accounting standards are created. In turn, regarding the convergence process there is a need to evaluate to what extent a trade-off from external to internal comparability takes place, i.e. there is no use in the foreign markets gaining an advantage in the allocation of capital if such a gain occurs at the expense of greater deficiency in the resource allocation process within this economy. The question is whether the gain in external comparability (between countries) empirically proved by some studies (Yip \& Young, 2012; DeFond, Hu, Hung \& Li 2011; Barth, Landsman, Lang \& Williams, 2013) occurs at the expense of decreased internal comparability (between companies in the same country - within country) generated by regulatory flexibility. To answer these practical questions, there is a need to examine how the regulatory flexibility process can impact comparability.

The main challenge of this research type is identifying a feasible window of accounting system change to iso- late the effects of regulatory flexibility. Many European countries have experienced changes in their accounting systems with mandatory IFRS adoption in 2005. However, there are few countries where this process was so clear and distributed as in Brazil. According to Carvalho and Salotti (2013), Brazil is a rare example of a country that has adopted the full international standard, not only concerning consolidated financial statements, but also individual statements. What we notice, in the Brazilian case, is the gradual change from a completely rule-based accounting standard, linked to tax standards and without much room for interpretation (Lopes, 2011; Lopes \& Walker, 2010) to rather flexible accounting standards and based on principles, such as the IFRS (Tweedie, 2007). According to the Foundation Institute for Accounting, Actuarial, and Financial Research and Ernst \& Young (2013, p. 7), in Brazil there was a "change from rule-based accounting to principle-based accounting." According to these entities, regulatory flexibility increased the complexity of procedures for recognizing, measuring, and disclosing accounting information, thus, greater subjectivity and higher degree of judgment were provided to the statements. It is also worth noticing that this change occurred in isolation, i.e. the other variables that could impact the outcomes of financial reports (and, as a consequence, comparability), such as incentives to managers, audit quality, level of enforcement, ownership structure, and institutional features (Holthausen, 2009) remained relatively constant within this period, making the Brazilian regulatory case the optimal example to investigate this research question.

\section{THEORETICAL FRAMEWORK}

\subsection{Concept of Comparability}

The view of comparability used in this research is the same adopted by agencies that regulate accounting: the Financial Accounting Standards Board (FASB) and the International Accounting Standards Board (IASB). According to these entities:

Comparability is the qualitative feature that enables users to identify and grasp similarities and differences between the items. Unlike other qualitative features, comparability is not related to a single item. Comparison requires at least two items (Financial Accounting Standards Board, 2010; International Accounting Standards Board, 2010).

According to Simmons (1967), with a view to make users able to effectively compare the economic and financial performance of a company to another one or the same company, over time, there is a need that companies sub- ject to the same economic event and the same institutional conditions recognize and measure patrimonial facts in a similarly way. Only disclosing numbers in the same way does not guarantee comparability; they must also represent the same goal. This is perhaps the main limitation of previous studies testing the comparability of financial reports. A large part of the previous research on the theme adopted metrics based on market concentration indices for accounting policies (Taplin, 2010). Such metrics capture only the ex-ante dimension of comparability and they do not link the economic event and its translation into the accounting model of companies, i.e. they are measurements related only to the inputs. For these models simply using the same accounting policy in the companies was already regarded as a measurement of comparability. Now, knowing whether economic events were the same for such a policy is another issue outside the scope of these metrics. This limitation ended up just restricting the application of indices of the measurement of accounting policies rather as a measurement 
of uniformity than actually comparability, according to the concept of the Financial Accounting Standards Board (2010) and the International Accounting Standards Board (2010).

The first measurement of comparability that managed to capture the two dimensions (ex-ante and ex-post) of the phenomenon was recently developed by DeFranco, Kotha- ri and Verdi (2011) and it was named as similarity of the accounting function. According to these authors, the reasoning underlying their model is grounded in the premise that the results provided by accounting are a translation of economic events to which an entity is subject, i.e. the accounting numbers are a function of economic events, which may be represented as follows:

\section{Financial Statements $i=f i$ [Economic Events]}

In this function, $\mathrm{fi}$ [ ] represents the accounting system of a firm i. DeFranco et al. (2011) state that two companies have comparable accounting systems if, for the same type of economic event, they produce similar accounting outputs. This way of measuring comparability has a big advantage, because, unlike the indices of harmonization, which are measurements calculated having the accounting model inputs as a basis (it is needed to calculate an index for each accounting policy), the model of similarity is a measurement of output, i.e. its number is a final measurement of comparability (DeFranco et al., 2011).

To operationalize the measurement of comparability in the model by DeFranco et al. (2011) two pieces of information are required: profit and return. Profit represents the final product of the accounting system, where a large part of choices in a company is reflected concerning the recognition and measurement of economic events to which it is subject. In turn, the return is the proxy adopted to represent the economic event. According to Beaver, Lambert and Ryan (1987), the accounting system recognizes economic events after the recognition of stock prices, i.e. price reflects faster economic events than profit (for empirical evidence see Aylward \& Glen, 2000, and Ryan, 1995, and, in Brazil, Brugni, Fávero, Flores, \& Beiruth, 2015, and Fávero, 2015). This representation allows us to infer that profit (final result of the accounting translation in the economic event) has a direct relationship with return (economic event), thus to obtain the measurement of comparability there is a need to calculate the time series of profit in relation to return. The linear coefficient and the slope coefficient of this line are the accounting function of the company.

To achieve a measurement of comparability there is a need to calculate the accounting functions for companies on an individual basis. Then, the economic event of a company is determined and we take advantage of functions of the other entities subject to the same economic events (e.g. companies in the same economic activity sector). The final measurement of comparability is the distance between these two functions given an economic event in common.

The model proposed by DeFranco et al. (2011) has its rationale linked to the concept of comparability underlying the conceptual framework, i.e. comparability is the feature of accounting information that allows us to identify similarities and differences between the accounting functions of two or more companies (International Accounting Standards Board, 2010; Financial Accounting Standards Board, 2010). Thus, if two companies have the same set of economic events, the more comparable their accounting functions, the more similar their accounting numbers.

\subsection{Standards Based on Rules or Principles}

Although there is no complete differentiation border between standards based on rules or principles, there is a key difference: their level of specificity. Kothari et al. (2010) claim that, in an extreme view, under a regulatory system based on principles, regulators define a range of principles and allow all interested parties to apply these principles in the specific economic contexts found. Conversely, in a system based on rules, regulators provide the same parties with detailed guides on how they should recognize, measure, and highlight the different economic contexts, minimizing the requirement to exert judgment by managers and other related parties.

Due to such aspects, a key issue for regulators is deciding the optimal level of discretion to be allowed to managers in their accounting practices. According to Kothari et al. (2010), the discretionary level of managers in the preparation of financial reports is related to the type of accounting standard to which they are subject. According to the authors, the debate between regulators of costs and benefits about allowing a greater amount of choices to determine accounting numbers is the foundation of discussion between standards based on rules or principles. 


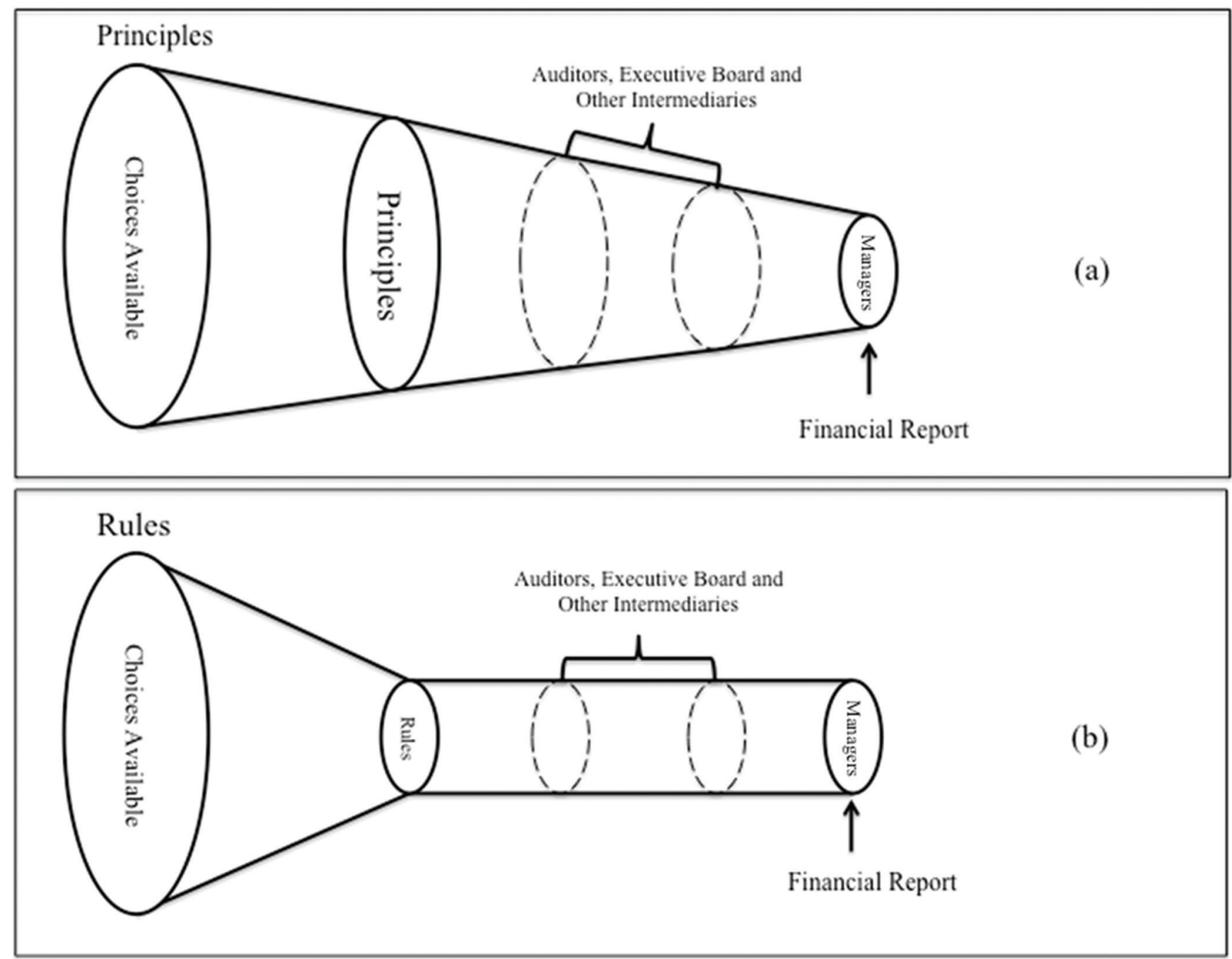

Figure 1 Differences between the spectra of accounting choices in the regulatory system based on principles compared to the system based on rules.

Source: Kothari et al. (2010).

In Figure 1 we observe the operation of the mechanics of the two types of regulatory standards regarding the accounting choices suitable to each of them. According to Kothari et al. (2010), the gradual border of financial choices between regulators, boards, accountants, and auditors of the motivating patrimonial event up to the occasional accounting method chosen takes the shape of a deep funnel in principle-based standards and the shape of a shallow funnel in rule-based standards. The funnel shape and depth, in fact, reflect the constraints of companies when applying their accounting policies. Such a limitation is a function of the autonomy degree to choose accounting policies guaranteed by the regulatory levels.

Kothari et al. (2010) claim that the idea, in theory, behind a principles-based system is setting broad limits of accounting choices and allowing companies, also their managers, auditors, and accountants to pursue accounting practices within these limits. The reasoning behind such a regulatory strategy is that managers have specific knowledge about the economic situation of their business, including regulatory, contractual, fiscal, and political en- vironments, therefore, they are able to meet more adequately the requirements of various contracting parties, as well as to take into account aspects that only providers of such information could make available when preparing their financial reports. In turn, in the rule-based system, the behavior forms and accounting choices are dictated by regulatory standards in a specific way, leaving the manager without much room for innovation, given that she/ he might have to fit her/his accounting policies in a frame that does not always reflect the various nuances of the dynamic business environment concerned (Securities and Exchange Commission, 2003).

\subsection{Previous Research Addressing Standards Based on Rules or Principles and its Impact on Financial Reports}

Despite the discussion on flexibility versus standardization is an old issue in the accounting scenario, it has gained an extra breath with the recent economic crises. Accounting frauds committed by the companies Enron and WorldCom raised an old argument about the exis- 
tence of bright lines in the accounting standards based on rules (Kothari et al., 2010) and how the standards based on principles could solve such problems. Anchored in this debate, there emerged some papers seeking to analyze the impact of each type of system in theoretical and empirical terms. The FASB in 2002 and the SEC in 2003 created committees to examine in greater depth the difference between standards based on rules or principles. Reports from the two committees reached similar conclusions. According to the Financial Accounting Standards Board (2002), the adoption of a regulatory system based on principles (rather than on rules) might result in a higher level of judgment on the part of those responsible for preparing financial reports. This greater subjectivity, in turn, might lead to accounting policy choices that better reflect the economic substance of transactions, increasing transparency, comparability, responsiveness to new phenomena, and exchange of funds across borders. The Securities and Exchange Commission (2003) also concluded that the regulatory system based on principles is superior, but the entity provided a distinction between the traditional system based on principles and that based on goals, whose effectiveness, according to the entity, is even bigger.

As for empirical papers addressing the differences between regulatory systems and their effects on the quality of accounting information or on how a manager determines her/his accounting policies, what takes advantage is also the standard based on principles. Webster and Thornton (2004) analyzed the quality of accruals among reports from the Canadian companies that reported according to their local standard and the U.S. accounting principles (U.S. generally accepted accounting principles - USGAAP). The researchers concluded that the quality of accruals is higher in the regulatory system based on principles from Canada than in the system based on rules from the USA. Kohlbeck and Warfield (2010) found, in turn, features in the system based on principles related to a higher quality of prediction by market analysts in their assessment reports. In turn, Mergenthaler (2009) has investigated the impact of the system based on rules on managing outcomes and found evidence that such a system has a significant relationship with the magnitude of management of outcomes and the likelihood that the manager is penalized by the market surveillance authority is lower than in the principle-based system, i.e. in stricter regulatory system companies practice more management of outcomes and are less likely to be punished.

Another study that investigated the relationship between the two accounting standard systems was Collins et al. (2012). The objective of this research was analyzing variation in the classification of leasing operations in both types of regulations. Collins et al. (2012) found robust evidence that companies subject to the USGAAP are more likely to classify their leasing operations as operational than the companies subject to the IFRS. The researchers also found evidence that the outcomes reported according to the international standard are less dispersed when compared with the outcomes reported according to the USGAAP. This suggests that variability in the final outcome of financial reports is lower in the principle-based system, something which contradicts the rationale of rule-based standards a little bit.

In the line of experimental studies, the results obtained also favor principle-based standards. Psaros and Trotman (2004) compared the judgments of management regarding the consolidation of accounting statements in two different regulatory environments, one tighter and another more flexible. Although both groups had the same incentive not to consolidate (and consolidation was the right response), the researchers were faced with a significantly greater number of individuals who choose not to consolidate in the regulatory system based on rules when compared to the system based on principles. According to the authors, their findings contradict the arguments that inaccurate standards taking into account the substance under the form makes them less effective to fight biases in financial reports when compared to rule-based standards. Corroborating the findings of Psaros and Trotman (2004), Agoglia et al. (2011) observed in their experiments that financial directors subject to a more flexible regulatory system are less exposed to aggressive practices in financial reporting than financial directors in stricter systems. Overall, based on these studies, we notice the existence of a proven superiority of the standard based on principles over the standard based on rules. Regulatory flexibility may fail to reduce variability in the outcomes disclosed in the financial reports, indeed, Collins et al. (2012) found the exact opposite.

\section{RESEARCH DESIGN}

Methodologically, this research may be classified as descriptive and, predominantly, quantitative. Data are secondary and they were collected resorting to the software Economática $^{\varpi}$ and the websites of the Brazilian Securities Commission (CVM) and the Brazilian Securities, Com- modities, and Futures Exchange (BM\&FBOVESPA). The dependent variable is the comparability of financial statements and the objective of this research is examining how such a measurement behaved in face of the regulatory flexibility that took place in Brazil within a time series from 
2004 to 2012. To measure comparability, we adopted as a metrics the model similarity of the accounting function devised by DeFranco et al. (2011). To test the behavior of the variable concerning the regulatory flexibility, we chose the panel data statistical approach.

\subsection{Comparability Measurement}

The measurement of comparability used in this research was the similarity of accounting function proposed by DeFranco et al. (2011). As a measurement of output, the comparability obtained by means of this model has some advantages, such as increased robustness in statistical analy- sis, lower bias of the researcher, and higher reliability in data collection. Moreover, it was widely used in recent studies on the theme (DeFranco et al., 2011; DeFond et al., 2011; Barth, Landsman, Lang \& Williams, 2012; Brochet, Jagolinzer \& Riedl, 2013; Lang, Maffett \& Owens, 2010; Fang, Li, Xin \& Zhang, 2012; Neel, 2013; Peterson, Schmardebeck \& Wilks, 2012; Yip \& Young, 2012; Barth et al., 2013; Sohn, 2011; Cascino \& Gassen, 2012; Kim, Kraft \& Ryan 2013), and this already guarantees an external validation to it.

The first step in the composition of such a metrics was estimating the individual accounting function of each company based on the last 12 quarters by using this equation:

$$
R O A_{i t}=\alpha_{i}+\beta_{i} \text { Return }_{i t}+\varepsilon_{i t}
$$

where:

$\mathrm{ROA}_{\mathrm{it}}=$ Quarterly net profit on the final total assets of firm i for non-consolidated period $t$.

Return $_{\mathrm{it}}=$ Quarterly average return of firm i for period $t$, calculated having as a basis the close stock price of those with greater presence adjusted for dividends and splits.

The use of stocks with bigger presence aimed to avoid distortions in the measurement of comparability that could arise due to a potential lack of trading of some ordinary shares. To select the type of share, we calculated the average number of trading days. We selected the types of share (ordinary or preferred) showing the greatest daily average presence within the period. After this selection, there was no exchange between the type of share from one quarter to another. This served to avoid the effect of such an exchange in return, as the prices of preferred and ordinary shares are different.

After estimating the parameters of individual functions, it was necessary to design the expected ROA $\mathrm{E}(\mathrm{ROA})$ - for each company having the regressions obtained as a basis. First, it was necessary to estimate the expected ROA specific to the company within the period according to this function:

$$
E(R O A)_{i i t}=\hat{\alpha}_{i}+\hat{\beta}_{i} \text { Return }_{i t}
$$

Later, we calculated the expected ROA for the same company with the estimators of other companies in the same sector, according to this equation:

$$
E(R O A)_{i j t}=\hat{\alpha}_{j}+\hat{\beta}_{j} \text { Return }_{i t}
$$

The idea is maintaining a steady economic event, by using the estimators of a company in an economic event of another one, thus the measurement of comparability is the average distance between these two functions for each quarter $-\mathrm{E}\left(\mathrm{ROA}_{\mathrm{iit}}\right)-\mathrm{E}\left(\mathrm{ROA}_{\mathrm{ijt}}\right)$. According to DeFranco et al. (2011), the closer the two functions, the greater comparability between companies.

To measure individual compability between pairs, we calculated the average proximity of each function for a period (quarter) according to this formula:

$$
C_{0 m p b} b_{i j t}=-\frac{1}{12} \times \sum_{t-11}^{t}\left|E(R O A)_{i i t}-E(R O A)_{i j t}\right|
$$


where:

$\mathrm{Compb}_{\mathrm{ijt}}=$ Relative individual measurement of comparability for company $i$ based on company $j$.

$\mathrm{E}\left(\mathrm{ROA}_{\mathrm{iit}}\right)=$ Return on assets expected for company i based on the estimators of company $i$ and the return of firm $i$ within the period $t$.

$\mathrm{E}\left(\mathrm{ROA}_{\mathrm{ijt}}\right)=$ Return on assets expected for company i based on the estimators of company $j$ and the return of firm $i$ within the period $t$.

The measurement of comparability obtained according to the equation above is a relative measurement, i.e. it measures the average distances between the functions of two isolated companies. For obtaining a measurement of general individual comparability with pairs in the sector there is a need to calculate the average of these distances between reference companies, according to this equation:

$$
C O M P M_{i t}=\frac{C o m p b_{i j t}}{n} \quad 5
$$

where:

$\mathrm{COMPM}_{\mathrm{it}}=$ Individual measurement of comparability for each company in relation to pairs in the sector.

$\mathrm{Compb}_{\mathrm{ijt}}=$ Relative comparability measurement of each pair of companies.

$\mathrm{n}=$ Number of companies in the sector (or those under comparison).

In relation to the original model by DeFranco et al. (2011) there were three adjustments in this study: in the estimation period of individual functions (16 to 12 quarters), in the deflator to determine the effect size (total assets), and in the measurement of profit used (due to the transition period, the measurement of operational profit originally employed has different elements before and after the international standards). The objective of profit in the model of comparability is representing the set of accounting choices made by the manager in a given period. The ideal might be using the comprehensive outcome, since this is the measurement that represents the largest number of possible accounting policies adopted by the manager. However, in this case, as the study period is prior to the IFRS adoption, this measurement did not exist, something which prevents its use. The second accounting measurement that covers more manager discretionary decisions is net profit, which, despite the possibility of being affected by leverage-related problems, constitutes a measurement that may be compared throughout the period before and after adopting the international standard. Net profit was also employed in other studies, such as Yip and Young (2012) and Brochet et al. (2013). Yip and Young (2012) also used ROA in the same way as calculated in this research. Both in this research and in other studies adopting similar adaptations (Yip \& Young, 2012; Lang et al. 2010; Cascino \& Gassen, 2012; Brochet et al., 2013) no significant bias was noticed in relation to the original measurement by DeFranco et al. (2011).

\subsection{Researched Universe and Data Collection}

The universe of companies used in this article was selected intentionally through the software Economática ${ }^{\varpi}$. The first selection needed was the primary country of research.
Having in mind that the aim of this article is identifying how regulatory flexibility impacts on comparability, we chose to use only one country to limit the effects of institutional and economic differences on the results obtained. Brazil was the country chosen because a well-known process of regulatory flexibility has taken place in it in recent years.

The second selection was made in the economic activity sector under analysis. To choose sectors, level 2 of the North American Classification System (NAICS) was used. Level 2 of the NAICS was used a large part of the studies investigating comparability within sectors (DeFranco et al., 2011; Yip \& Young, 2012; Lang et al., 2010). The selected sectors were those with more than a company having quarterly data available from 2002 to 2012 . The accounting function is estimated through quarterly data for three years before the base period. Therefore, to calculate the year 2004 data from early 2002 were needed.

Overall, nine sectors met this condition, excluding the banking sector, because banks do not file their quarterly statements in accordance with the IFRS. In the end, eight economic activity sectors were analyzed (heavy construction; electric power companies; transport equipment industry; metal products industry; textile industry; chemical industry; steelworks; and telecommunications). Embraer S.A. and Gerdau S.A. were excluded from the study because the first has as its functional currency U.S. dollars and its activities are primarily concentrated abroad, something which could distort comparability to the other companies in the sector. The second was excluded because it has a wholly owned subsidiary in the same sector, something which could also bias the outcomes. In the end, a total of 54 companies with data in the time series between 2002 and 2012 were analyzed.

After determining the companies addressed in the analysis, it was time to collect the data needed for the study. To obtain all information needed to conduct the research we used: the software Economática ${ }^{\circledR}$ (for indicators and variables related to financial and market statements), the site of the CVM (for data related to audit companies), and the site of the Bovespa (for information on corporate governance). 


\subsection{Data Analysis}

To answer the question proposed by this research, we chose the panel data analysis technique. The theoretical model adopted in this research may be represented as follows:

\section{Comparability $=f(D . Y E A R ;$ Controls $)$}

The variable D.YEAR is qualitative and it was operationalized with dummies for each year representing the period from 2005 to 2012 where the reference year was 2004. The year 2005 was chosen as the starting point, because the first rather concrete initiatives occurred in it (such as the creation of the Brazilian Accounting Statements Committee (CPC) and the issuance of CPC 01 on the impairment test) regarding the convergence of Brazil to the international standard. The remaining periods prior to the year 2010 represent the regulatory transition period and since 2010 the period is regarded as full-IFRS. The year 2004 was chosen as a base, because it is a relatively recent period and prior to the effect of convergence to the IFRS. As it takes three previous years of data to calculate the accounting function, going back a longer time might cause a considerable decrease of companies with data available to analysis.

In turn, regarding the control variables, theoretically the measure of comparability used in this research has a very close relationship to accounting choice theories and quality of profits. For instance, the variable Earnings per share (EPS) is a measurement that reflects company's performance to a shareholder and it is widely used in contracts with variable remuneration for managers (Ittner, Larcker \& Rajan, 1997; Young \& Yang, 2011). Due to this fact, in order to achieve a specified profitability goal, managers may engage in accounting practices that do not reflect the economic reality of their business, thus affecting the comparability of financial reports.

Dechow, Ge and Schrand (2010) distribute the determinants of profit quality into six categories: (i) companies' characteristics; (ii) financial reporting practices; (iii) governance and control mechanisms; (iv) audit; (v) capital market incentives; and (vi) external factors. In this article, the practical categories of financial reports and external factors are already naturally controlled by the sectors. The other variables, with their references, are displayed in $\mathrm{Ta}$ ble 1 .

Table 1

Variables used in the model

\begin{tabular}{cccc}
\hline \multicolumn{4}{c}{ Dependent Variables } \\
\hline Variable & Description & Operation & Main References \\
\hline & Average individual comparability & $R O A_{i t}=\alpha_{i}+$ & \\
COMPM & based on pairs in the sector. & $\beta_{i}$ Return $_{i t}+\varepsilon_{i t}$ & DeFranco et al. (2011)
\end{tabular}

\begin{tabular}{|c|c|c|c|}
\hline \multicolumn{4}{|c|}{ Independent Variables of Interest and Control } \\
\hline Variable & Description & Operation & Main References \\
\hline YEAR & $\begin{array}{l}\text { Regulatory flexibility period } \\
\text { occurred in Brazil. }\end{array}$ & $\begin{array}{c}\text { Dummies representing the years } \\
\text { between the period } 2005 \text { to } 2012 \text {. } \\
\text { The base year was } 2004 \text {. }\end{array}$ & $\begin{array}{c}\text { Lopes (2011); Carvalho and } \\
\text { Salotti (2013) }\end{array}$ \\
\hline EARNINGS PER SHARE & $\begin{array}{l}\text { It serves to represent performance } \\
\text { for shareholders. }\end{array}$ & (Net Profit)/(Shares in Circulation) & $\begin{array}{c}\text { Dechow et al. (2010); Doyle, Ge } \\
\text { and Mcvay (2007) }\end{array}$ \\
\hline OPERATING LEVERAGE & $\begin{array}{l}\text { Measurement of operational } \\
\text { performance and the company } \\
\text { cost structure. }\end{array}$ & $\begin{array}{c}\text { (Gross Profit)/(Gross Profit - Selling } \\
\text { Expenses and Administrative } \\
\text { Expenses })\end{array}$ & $\begin{array}{c}\text { Sohn (2011); Francis, Hanna and } \\
\text { Vincent (1996) }\end{array}$ \\
\hline DEBT-EQUITY RATIO & $\begin{array}{l}\text { It serves to measure company } \\
\text { gross indebtedness in relation to } \\
\text { its equity. }\end{array}$ & (Gross Indebtedness)/(Equity) & $\begin{array}{l}\text { Dhaliwal, Salamon and Smith } \\
\text { (1982); Lilien and Pastena (1981) }\end{array}$ \\
\hline GROWTH & $\begin{array}{l}\text { Increased or decreased percenta- } \\
\text { ge in company gross revenue in } \\
\text { relation to the previous year. }\end{array}$ & $\begin{array}{c}\text { (Gross Revenue }{ }_{t}-\text { Gross Reve- } \\
\left.\text { nue }_{t-1}\right) / \text { Gross Revenue }_{t-1}\end{array}$ & $\begin{array}{c}\text { Lee, Li and Yue (2006); Dechow } \\
\text { et al. (2010); Mcvay, Nagar and } \\
\text { Tang (2006) }\end{array}$ \\
\hline PRICE BOOK RATIO & $\begin{array}{l}\text { It measures business growth } \\
\text { expectations for the market. }\end{array}$ & $\begin{array}{c}\text { (Amount of Ordinary Shares x } \\
\text { Price)/(Equity) }\end{array}$ & $\begin{array}{c}\text { Lee, Li and Yue (2006); Dechow } \\
\text { et al. (2010); Mcvay, Nagar and } \\
\text { Tang (2006) }\end{array}$ \\
\hline SIZE & $\begin{array}{l}\text { Total company assets turned into } \\
\text { a logarithmic base. }\end{array}$ & Ln Total Assets & $\begin{array}{c}\text { Watts and Zimmerman (1986); } \\
\text { Doyle et al. (2007) }\end{array}$ \\
\hline
\end{tabular}


Table 1

Contin.

\begin{tabular}{|c|c|c|c|}
\hline RISK & Annual company beta (365 days). & | Beta | & $\begin{array}{c}\text { Dechow et al. (2010); Watts and } \\
\text { Zimmerman (1986) }\end{array}$ \\
\hline CAPITAL INTENSITY & $\begin{array}{l}\text { It measures the level of capital } \\
\text { tangibility. }\end{array}$ & (Permanent Assets)/(Equity) & $\begin{array}{l}\text { Himmelberg, Hubbard and Palia } \\
\text { (1999) }\end{array}$ \\
\hline PRESENCE & It measures liquidity. & $\begin{array}{l}\text { (Number of days with shares tra- } \\
\text { ded)/( Total number of trading days) }\end{array}$ & Watts and Zimmerman (1986) \\
\hline GOVERNANCE & $\begin{array}{l}\text { It measures if the company adhe- } \\
\text { red to some level of corporate } \\
\text { governance in Bovespa. }\end{array}$ & $\begin{array}{c}\text { Dummy variable with } 2 \text { categories: } \\
\text { it has ( } 1 \text { ) or it does not have (0) a } \\
\text { level of governance }\end{array}$ & $\begin{array}{c}\text { Doyle et al. (2007); Ashbaugh, } \\
\text { Collins, Kinney and LaFond } \\
\text { (2008) }\end{array}$ \\
\hline CONCENTRATION & $\begin{array}{l}\text { Percentage of ordinary shares } \\
\text { held by the company's largest } \\
\text { shareholder. }\end{array}$ & $\begin{array}{l}\% \text { ordinary shares concentrated on } \\
\text { the hands of the largest shareholder }\end{array}$ & $\begin{array}{l}\text { LaFond and Roychowdhury } \\
\qquad \text { (2008) }\end{array}$ \\
\hline $\mathrm{BIG} 4$ & $\begin{array}{l}\text { Firm auditing the balance in the } \\
\text { given period. }\end{array}$ & $\begin{array}{c}\text { Dummy variable with } 2 \text { categories: } \\
\text { audited by a BIG4 (1) and not } \\
\text { audited by a BIG4 (0) }\end{array}$ & $\begin{array}{c}\text { Lawrence, Minutti-Meza and } \\
\text { Zhang (2011) }\end{array}$ \\
\hline AUDITOR CHANGE & $\begin{array}{l}\text { Dichotomous variable measuring } \\
\text { if the company changed auditors } \\
\text { in relation to the previous period. }\end{array}$ & $\begin{array}{c}\text { Dummy variable with } 2 \text { categories: } \\
\text { changed ( } 1) \text { and did not change }(0) \\
\text { the audit firm }\end{array}$ & $\begin{array}{c}\text { Lawrence, Minutti-Meza and } \\
\text { Zhang (2011) }\end{array}$ \\
\hline SECTOR & NAICS classification level 2. & $\begin{array}{l}\text { Dummies representing the eight } \\
\text { sectors: Electric Power (Reference); } \\
\text { Construction; Transport Equipment } \\
\text { Ind.; Metal Products Ind.; Textile } \\
\text { Ind.; Chemical Ind.; Steelworks; } \\
\text { and Telecommunications }\end{array}$ & $\begin{array}{l}\text { Verrecchia and Weber (2006); } \\
\text { Bagnoli and Watts (2010) }\end{array}$ \\
\hline
\end{tabular}

Obs.: For companies with negative equity, the indicators related to such data were not calculated, leaving the observation with missing value in this information. For further development in the justification and rationale behind the choice of these control variables see the thesis by Ribeiro (2014).

Source: Prepared by the authors.

As there is no robust study addressing which are the company characteristics able to affect the comparability of financial reports, this research resorted to papers related to accounting choices and profit quality to select its control variables.

Concerning the panel model, this may be classified as short (larger number of individuals than years) and strongly balanced (all individuals were maintained over the years). The technique chosen in model estimation was pooled ordinary least square (POLS), since it has proved to be more suitable than the model that takes into account the existence of random effects, according to the outcome of the Breusch-Pagan LM Test.

Before data processing, a multivariate treatment for outliers was conducted with data. The technique employed was that proposed by Hadi (1992) and, as the purpose of this research is checking the behavior trend over the years measuring comparability, the existence of outliers could affect the outcomes. Even so, for comparative purposes, the results working with and without treatment of outliers were tabulated, as recommended by Wooldridge (2013). According to the results obtained (not shown), there was no significant distortion in regressors.

\section{PRESENTATION AND ANALYSIS OF RESULTS}

Table 2

\begin{tabular}{|c|c|c|c|c|c|c|}
\hline Variable & Obs. & Average & S. Deviation & P10\% & Median & P90\% \\
\hline Intercept & 486 & 1.427 & 2.667 & -1.112 & 1.500 & 4.295 \\
\hline Coefficient & 486 & 0.014 & 0.063 & -0.026 & 0.005 & 0.065 \\
\hline $\mathrm{R} 2$ & 486 & 0.109 & 0.144 & 0.002 & 0.060 & 0.297 \\
\hline
\end{tabular}

Source: Prepared by the authors. 
Before analyzing the descriptive statistics of the variables took into account in the survey, the outcomes of the elements of individual accounting functions of the companies used in this study and estimated according to Equation 1 (Table 2) were demonstrated. DeFranco et al. (2011), in a sample with 71,295 observations in the United States, found an average $\mathrm{R}^{2}$ for individual functions of
0.1218 , a value of 0.0026 for companies within the $10 \%$ percentile and a value of 0.3217 for companies within the $90 \%$ percentile. What may be drawn from such an analysis is that the values of individual functions of the Brazilian companies adopted in this study were similar to the values of elements of functions of the U.S. companies in the original paper by DeFranco et al. (2011).

Table 3 Descriptive statistics of the variables

\begin{tabular}{|c|c|c|c|c|c|c|c|c|}
\hline VARIABLE & $\mathbf{N}$ & Average & $\begin{array}{l}\text { Overall Stan- } \\
\text { dard Deviation }\end{array}$ & $\begin{array}{c}\text { Standard } \\
\text { Deviation } \\
\text { Between }\end{array}$ & $\begin{array}{c}\text { Standard } \\
\text { Deviation } \\
\text { Within }\end{array}$ & Min. & Max. & Median \\
\hline СОМРM & 474 & -2.6335 & 1.4055 & 0.9683 & 1.0522 & -7.89 & -0.33 & -2.28 \\
\hline $\begin{array}{c}\text { EARNINGS PER } \\
\text { SHARE }\end{array}$ & 473 & 1.3383 & 2.2934 & 1.8389 & 1.4229 & -7.18 & 10.1 & 0.79 \\
\hline OP LEV DEGREE & 452 & 1.067 & 1.2434 & 1.0945 & 0.726 & -3.7 & 4.83 & 1.2 \\
\hline $\begin{array}{c}\text { DEBT-EQUITY } \\
\text { RATIO }\end{array}$ & 432 & 41.9209 & 44.6433 & 39.5346 & 23.4694 & 0 & 208.06 & 27.69 \\
\hline SIZE & 486 & 21.3838 & 1.6549 & 1.6295 & 0.3568 & 17.58 & 25.44 & 21.5 \\
\hline GROWTH & 451 & 0.1006 & 0.1838 & 0.0678 & 0.1716 & -0.51 & 0.69 & 0.1 \\
\hline PRESENCE & 486 & 74.9881 & 30.0698 & 25.8319 & 15.7452 & 4.42 & 100 & 90.69 \\
\hline $\begin{array}{l}\text { PRICE BOOK } \\
\text { RATIO }\end{array}$ & 460 & 1.5664 & 1.3217 & 1.1323 & 0.8182 & -2.76 & 6.2 & 1.31 \\
\hline RISK & 477 & 0.952 & 0.3982 & 0.3805 & 0.1272 & 0.09 & 2.83 & 0.94 \\
\hline CAP INTENSITY & 444 & 56.369 & 64.8821 & 53.0425 & 37.4792 & 0 & 295.34 & 33.02 \\
\hline CONCENTRATION & 475 & 62.4284 & 25.0134 & 23.3737 & 9.1221 & 6.77 & 99.97 & 59.44 \\
\hline BIG4 & 486 & & & & & 0 & 1 & \\
\hline YEAR & 486 & & & & & 2004 & 2012 & \\
\hline $\begin{array}{l}\text { AUDITOR } \\
\text { CHANGE }\end{array}$ & 486 & & & & & 0 & 1 & \\
\hline GOVERNANCE & 486 & & & & & 0 & 1 & \\
\hline
\end{tabular}

Source: Prepared by the authors.

Based on Table 3, it may be initially observed that the variable related to time (YEAR) is invariant between companies (standard deviation between equal to zero), since data are shown as a strongly unbalanced panel. Furthermore, although the variations between and within have almost the same magnitude for the dependent variable, the other variables (explanatory in the model proposed) show greater variation between than within, except for the variables GROWTH and AUDITOR CHANGE. Thus, POLS models were estimated and considering both fixed and random effects through different types of estimation, because while a certain variable with higher variance within (e.g. the variable GROWTH) can lead the model estimated through fixed effects to be the most suitable, by considering that the terms of the intercept are correlated with this variable, another variable with greater variance between (e.g. the variable PRICE BOOK RATIO) can lead, but not necessarily, the model estimated through random effects to be the most suitable, by considering that the terms of the intercept are not correlated with terms of the idiosyncratic panel error. In the end, the POLS model was more robust before the suitability tests and it was shown in this research.

The results obtained in this research to measure comparability based on companies in the same sector (COM$\mathrm{PM}=-2.634)$ were very similar to those obtained by studies previously conducted in other countries. DeFranco et al. (2011), Fang et al. (2012), and Sohn (2011) found average values of $-2.7,-2.03$, and -1.907 , respectively, in their analysis with U.S. companies. In turn, Peterson et al. (2012), who analyzed the European companies listed in the U.S. stock market, found an average of -2.597 . These results demonstrate that the measurement of comparability obtained in this study is in line with the same measurements achieved at the international level, i.e. no biases were found due to adaptations proposed in this research. 


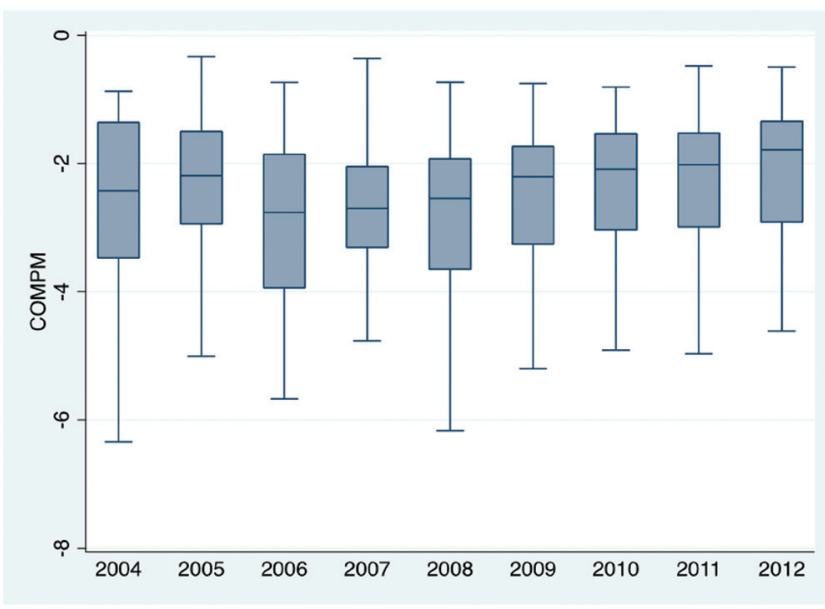

Figure 2 Behavior of comparability within the period examined in the research.

Source: Prepared by the authors.

Regarding the behavior of comparability within the transition period, as observed in Figure 2, in general terms, a slight increase was observed in average comparability between the years 2004 and 2005. This growth was followed by a decline to the same extent during the early transition period reversed since 2008 , a period coinciding with the sharpest efforts (larger number of CPC statements) to adopt the international standard in Brazil. Concerning the companies with worse comparability measurements, we noticed a gain in comparability after 2004, remaining stable within the transition period and the introduction of the IFRS. In turn, for higher comparability, their behavior showed a decrease within the early years of transition and a recovery after 2008 , a behavior similar to the overall average. It is inferred, through this evaluation, that the behavior of comparability of companies with higher measurements is different from the behavior of companies with the worse comparability within the transition period. Comparability measurements focused on the $90 \%$ percentile apparently suffered greater variation with regulatory changes during the years 2004 to 2012. This behavior was also observed in the overall average. For measurements focused on the $10 \%$ percentile there were no marked variations in the transition period. What may be concluded from these results is that, in general and without considering other factors that could influence the relationship of comparability, there was a transient loss of comparability during the early regulatory transition period only for companies that have demonstrated a higher level of comparability. For the worst companies and those with average levels, these differences were not so clear.

It is noteworthy that the subprime crisis triggered in the USA may have, in a way, impacted the outcomes of measuring comparability (having in mind that this measurement used market return on its composition). Although the crisis has produced a greater shock in the years 2007 and 2008 and decrease in the level of comparability has begun on average in the year 2006, Costa, Reis and Teixeira (2012) point out that in the period 2007 and 2008, in Brazil, the relevance of profit for the market was significantly lower when compared to the other years without crisis. Silva (2013) also shows in a thesis that there was a considerable increase in the exercise of discretion by managers during two periods in Brazil. The first period was during the crisis (2007 and 2008 ) and the second took place in the first year of adoption of the international standard (2010).

It becomes clear in Figure 2 that the comparability level was lower in the years 2007 and 2008, but not in the year 2010 , even though this has been a period with much use of discretionary accruals (Silva, 2013). This aspect allows us to infer that perhaps there was an effect of the crisis on the measurement of comparability that coincided with the regulatory transition period. However, as described above, this effect was only observed for companies with higher levels of comparability. On average, it was not clear.

Table 4 Results of the multivariate model

\begin{tabular}{|c|c|c|c|c|c|c|}
\hline \multirow{2}{*}{ СОМРМ } & \multicolumn{2}{|c|}{ Years } & \multicolumn{2}{|c|}{ Full } & \multicolumn{2}{|c|}{ Stepwise } \\
\hline & Coef. & $t$ & Coef. & $t$ & Coef. & $t$ \\
\hline 2005 & 0.3239 & $2.09 * *$ & 0.4079 & $1.86^{*}$ & & \\
\hline 2006 & -0.2063 & -0.82 & 0.0467 & 0.14 & & \\
\hline 2007 & 0.0001 & 0.00 & 0.4247 & 1.52 & & \\
\hline 2008 & -0.1279 & -0.55 & 0.0068 & 0.03 & & \\
\hline 2009 & 0.0135 & 0.06 & 0.4249 & 1.36 & & \\
\hline 2010 & 0.2690 & 1.02 & 0.4458 & 1.27 & & \\
\hline 2011 & 0.3736 & 1.35 & 0.6233 & $1.87^{*}$ & 0.4122 & $2.51^{* *}$ \\
\hline 2012 & 0.4310 & 1.57 & 0.7516 & $2.41^{* *}$ & 0.5496 & $3.53^{* * *}$ \\
\hline $\begin{array}{l}\text { EARNINGS PER } \\
\text { SHARE }\end{array}$ & & & 0.0165 & 0.39 & & \\
\hline OP LEV DEGREE & & & 0.2547 & $4.70^{* * *}$ & 0.2719 & $5.16^{* * *}$ \\
\hline $\begin{array}{l}\text { DEBT-EQUITY } \\
\text { RATIO }\end{array}$ & & & 0.0035 & 1.23 & & \\
\hline SIZE & & & 0.0364 & 0.40 & & \\
\hline GROWTH & & & 0.0000 & 0.00 & & \\
\hline PRESENCE & & & 0.0036 & 0.95 & & \\
\hline
\end{tabular}


Tabela 4 Contin.

\begin{tabular}{|c|c|c|c|c|c|c|}
\hline PRICE BOOK RATIO & & & -0.2166 & $-2.91 * * *$ & -0.1935 & $-2.71 * * *$ \\
\hline RISK & & & -0.0143 & -0.04 & & \\
\hline CAP INTENSITY & & & -0.0012 & -0.70 & & \\
\hline CONCENTRATION & & & -0.0044 & -1.06 & & \\
\hline AUDITOR CHANGE & & & 0.0560 & 0.50 & & \\
\hline GOVERNANCE & & & -0.0596 & -0.23 & & \\
\hline BIG4 & & & -0.1052 & -0.64 & & \\
\hline CONSTRUCTION & & & 1.4687 & $4.09^{* * *}$ & 1.6426 & $10.24^{* * *}$ \\
\hline TRANSPORT EQ. & & & -0.6828 & $-2.26^{* *}$ & -0.4627 & $-2.37^{* *}$ \\
\hline METALS & & & 0.4928 & 1.29 & & \\
\hline TEXTILE & & & -1.6001 & $-3.19 * * *$ & -1.4203 & $-3.73 * * *$ \\
\hline CHEMICAL & & & -1.3407 & $-5.72 * * *$ & -1.2491 & $-6.05^{* * *}$ \\
\hline STEELWORKS & & & -0.4166 & -1.52 & & \\
\hline TELECOMM & & & -0.6694 & -1.49 & & \\
\hline CONSTANT & -2.7565 & $-11.54^{* * *}$ & -3.3355 & -1.54 & -2.4759 & $-15.39 * * *$ \\
\hline $\mathrm{R}^{2}$ & \multicolumn{2}{|c|}{0.0244} & \multicolumn{2}{|c|}{0.3606} & \multicolumn{2}{|c|}{0.2881} \\
\hline ROOT MSE & \multicolumn{2}{|c|}{1.4002} & \multicolumn{2}{|c|}{1.0945} & \multicolumn{2}{|c|}{1.1204} \\
\hline $\mathrm{F}$ & \multicolumn{2}{|c|}{$3.57^{* * *}$} & \multicolumn{2}{|c|}{$114.06^{* * *}$} & \multicolumn{2}{|c|}{$87.19^{* * *}$} \\
\hline N & \multicolumn{2}{|c|}{474} & \multicolumn{2}{|c|}{350} & \multicolumn{2}{|c|}{350} \\
\hline
\end{tabular}

Obs.: * $/ * * / * * *$ denote two-tailed significance levels at $0.10 / 0.05 / 0.01$, respectively. The regressions above were estimated with OLS. In the full model we used the option with robust clustered standard errors in individuals. In the stepwise model we adopted the backward criteria with a 0.05 cutoff. The constant absorbed the following categories for dummy variables: YEAR $=2004$, AUDITOR CHANGE $=$ No and GOVERNANCE $=$ No, BIG4 = No, SECTOR $=$ ELECTRIC POWER. The models were obtained through the following equation and they vary according to the presence of controls:

COMPM $_{i, t}=\beta_{0}+\beta_{1}^{2005_{i, t}}+\beta_{2} 2006_{i, t}+\beta_{3} 2007_{i, t}+\beta_{4} 2008_{i, t}+\beta_{5} 2009_{i, t}+\beta_{6} 2010_{i, t}+\beta_{7} 2011_{i, t}+\beta_{8} 2012_{i, t}+\beta_{n}$ Control Variables $_{i, t}+\varepsilon_{i, t}$

Source: Prepared by the authors.

Table 4 displays the outcomes of the impact of the regulatory transition period on the average individual comparability (COMPM). As we can see, the full model has an explanatory power of 0.3606 . This number is similar to those obtained by studies related to this research (DeFranco et al., 2011, found an average of $20 \%$ in their models; DeFond et al., 2011, an average of 36\%; and Yip \& Young, 2012, an average of $34.1 \%)$. The overall significance of the model was also robust at a 0.01 significance level. Ramsey's test and VIF statistics showed that the model has no omitted variable bias $(\mathrm{F}=1.09$; Prob $>\mathrm{F}$ $=0.3527$ ), nor multicollinearity problems (Fávero, 2015). The average statistics of the variance inflation factor was 2.02 and the variable with highest VIF was Size (4.38) and it was far below the 10 recommended for multicollinearity problems (Wooldridge, 2013).

We notice, having the outputs obtained as a basis, that there was no significant loss of comparability in any model over the period analyzed. During the regulatory transition (2005 to 2009) there were no negative significant differences. After the IFRS adoption, in the full model and in stepwise, significant and positive outcomes were found for the years 2011 and, especially, 2012 (period regarded as full-IFRS due to the fact that individual financial functions have been estimated only by using data since 2010). Concerning the control variables, the sectors, the degree of operational leverage, and the price-to-book indicator (PBR) were significant. The degree of operational levera- ge measures the sensitivity level of profit variation in relation to variation in the activity volume, i.e. this degree is directly determined by company cost structure. The greater the company ability to leverage profit, the higher its fixed costs in relation to its variable cost. If fixed costs are higher in relation to variable costs, manager ability to manage these costs on an operational basis will be lower and comparability will be higher. This relationship was found empirically by Sohn (2011), who tested the effect of comparability on management of outcomes. Sohn (2011) concluded that managers of companies with higher comparability tend to manage more outcomes on an operational basis than by using accruals. Since a higher degree of operational leverage hinders management of variable costs, it is expected that this indicator has a direct relationship with comparability, i.e. the greater the Operating Leverage, the greater comparability may be observed and this was found in the research. In turn, the indicator PBR is related to the potential company growth capacity and it showed a negative relationship with comparability. This follows what is recommended by the theory on management of outcomes, i.e. the higher actual or potential growth, the worse comparability may be observed. Lee, Li and Yue (2006) claim that the main purpose of managers to manage outcomes is influencing the market price of shares of their companies. The authors add that the endogenously determined market response to profit is more sensitive for companies with high gro- 
wth rate or potential growth. This gives managers greater motivation to manage outcomes and it apparently affects the comparability of their financial reports.

The last significant control variable were the economic activity sectors. The low $\mathrm{R}^{2}$ obtained with the model without controls (0.02) when compared to the model with these variables and the number of sectors with significant differences in relation to the base sector in the model constitutes strong evidence that the behavior of comparability was not homogeneous within the various economic activity sectors.

The sectors with higher average values for comparability were heavy construction, metal industry, steelworks, and electric power, respectively. The sectors of electric power, heavy construction, and metal industry showed rather concentrated values for measuring comparability. The sectors showing the less dispersed measurements were also those with higher levels of comparability (except steelworks, which had a relatively low average, but a high dispersion between quartiles). A possible reason for the existence of significant differences between sectors is the level of competitiveness within them. According to Datta, Iskandar-Datta and Singh (2013), the companies operating in more competitive sectors are more likely to manage outcomes. Corroborating Datta et al. (2013), Verrecchia and Weber (2006) found evidence that the level of transparency in sectors with greater competition decreases significantly. Besides competitiveness, Bagnoli and Watts (2010) indicate other factors related to sectoral characteristics which could influence the level of management of outcomes. The researchers found empirical evidence in their study that companies having similar production technologies, whose production is governed by chemical or physical procedures (in contrast to the services sector), and the companies operating in mature markets are less prone manage outcomes. The authors have also found that firms with a larger product portfolio manage more their profits.

The outputs obtained in Table 4 may be associated with discoveries by Datta et al. (2013), Verrecchia and Weber (2006) and Bagnoli and Watts (2010). The sector with the smallest number of companies, i.e. lowest competitiveness, in this research was heavy construction (3), and it showed the highest level of comparability. Another sector regarded as having low competitiveness is electric power. Although it has a larger number of companies than the other sectors, the activity of generating and distributing electric power in Brazil is highly regulated and the companies are required to comply with market guidelines dictated by a regulatory agency. This aspect may decrease the level of competitiveness in the sector.
The sectors that obtained the worst average values in the levels of comparability were the clothing industry and the chemical industry. These economic activities, unlike sectors such as electric power and heavy construction, have a large portfolio of products and they allow greater diversification of sub-activities in the same classification. For instance, a company that manufactures clothes has a range of options much more diversified in its production (canvas, fabrics, clothing, etc.) than a company producing and distributing electric power. This greater diversity of products and activities may have reduced the level of comparability between companies in such sectors.

To finish, as noticed by Silva (2013), in the years 2007, 2008, and 2010 there was a great increase in the level of use of discretionary accruals by managers responsible for preparing the financial reports of listed Brazilian companies. The results obtained having the model of Table 4 as a basis demonstrate that, although there was a higher level of subjectivity during the transition period (either due to regulatory flexibility or as a result of the crisis period), there was no significant loss of comparability. These findings are consistent with outcomes obtained in previous research and they show that regulatory flexibility does not have a negative impact on comparability, on the contrary: their effect is seemingly positive. Agoglia et al. (2011) in their experiment regarding the standard on leasing, found a significantly lower variation between the decisions by preparers of financial reports in an environment with less accurate accounting standards. According to the authors, this suggests that, unlike what is advocated by some parties related to the accounting regulatory process, applying accounting standards rather focused on principles instead of rules does not result in lower comparability. In the same vein, Collins et al. (2012) found that the dispersion of leasing classification between the IFRS and the U.S. standard is not higher. The researchers recommend, based on the results of their research, that the concerns expressed by the Securities and Exchange Commission (2003) and Sunder (2009) in relation to the increased dispersion of accounting outcomes in face of the use of regulations based on principles are unjustifiable. Dye and Verrecchia (1995) follow the same line and indicate that the flexibility of an accounting standard is needed so that managers can differentiate their businesses and their various nuances to investors. The concept of comparability advocated for by the Financial Accounting Standards Board (2010) and the International Accounting Standards Board (2010) observes these differences and, as seen through the results of this research, the measurement of comparability had a significant gain with regulatory flexibility.

\section{FINAL REMARKS}

Adopting international standards in the Brazilian accounting context greatly increased the need for judgment (discretionary power) by managers in the preparation of their financial reports. This occurred because Brazil re- 
placed a standard based on rules and having a strong link with fiscal accounting by a standard based on principles with an emphasis on transparency, fundamentals of the IFRS. The main objective of this research was investigating how the regulatory flexibility process that culminated in IFRS adoption in Brazil affected the level of comparability within country in companies operating in the Brazilian market.

The results obtained in the study concerning comparability between various companies operating in the same economic activity sector (COMPM) were stable during the transition period and they increased significantly after the adoption of international standards. Although this research has found various specific behaviors for companies with higher levels of comparability and between the different sectors of economic activities, generally no significant losses were observed in the level of comparability (COMPM) during the regulatory transition period, on the contrary: on average, there was a significant increase in the year 2012 (regarded as full-IFRS because it addresses only data after 2010) when compared to the year 2004.

The results obtained in this paper meet the research objective of investigating how comparability reacted to the flexibility process of accounting standards that took place in Brazil in recent years and empirically validate the hypothesis that increasing the discretionary power of a manager does not decrease comparability of financial reports. This research found strong empirical evidence that increased flexibility in the accounting standards that took place in recent years in Brazil did not affect the comparability of financial reports of companies evaluated now. These findings are in line with Dye and Verrecchia (1995). According to them, when accounting principles (generally accepted accounting principles - GAAP) are strict, all firms should apply the same accounting procedure (e.g. research and development costs should be included in expenses within the period). In contrast, when the GAAP allow complete discretion, all economically viable procedure is allowed. Dye and Verrecchia (1995) highlight that when the GAAP have such a rich variety of procedures, the pro- fits of various companies, first, should be more comparable than when the accounting standard is strict. This is so because, if each company selects an accounting procedure suitable to its economic circumstances, one dollar in accounting profit is equal to one dollar in economic gain, resulting in accounting profits more comparable between companies.

Just as in Collins et al. (2012) and Agoglia et al. (2011), this research has shown that the arguments of those advocating for a strict regulation to achieve comparability are refuted. The results obtained in this research legitimized this viewpoint and proved empirically that, with increased regulatory flexibility, comparability has not decreased, on the contrary, the increased discretionary power of a manager derived from the transition to international standards in Brazil, in general, increased significantly the comparability between financial reports of companies analyzed in this research.

Like any scientific work, this paper also has some limitations. The sample is not probabilistic, something which prevents the generalization of results. The accounting effects of policies that go through the comprehensive result are beyond the scope of this measurement. Although the comprehensive result may carry the effects of accounting policies that are relevant to measure the performance of a company, this study chose to use profit for two main reasons. First, the empirically comprehensive result does not reflect a measurement of performance higher than profit for the period (Dhaliwal, Subramanyam \& Trezevant, 1999) and second, before adopting international standards in Brazil, this was not a measure usually adopted.

Some gaps have been left for this paper to be addressed in further research. This research has not tested if there is a direct relationship between increasing the amount of discretionary accruals and comparability. It also did not evaluate which are the possible explanations for the result obtained from auditors and sectoral differences. These issues are open and they may be analyzed in further research.

\section{References}

Agoglia, C., Doupnik, T., \& Tsakumis, G. (2011). Principles-based versus rules-based accounting standards: the influence of standard precision and audit committee strength on financial reporting decisions. The Accounting Review, 86(3), 747-767.

Ashbaugh, H. (2001). Non-US firms' accounting standard choices. Journal of Accounting and Public Policy, 20, 129-153.

Ashbaugh, H., Collins, D. W., Kinney, W. R.; \& Lafond, R. (2008). The. effect of sox internal control deficiencies and their remediation on accrual quality. The Accounting Review, 83(1), 217-250.

Ashbaugh, H., \& Pincus, M. (2001). Domestic accounting standards, international accounting standards, and the predictability of earnings. Journal of Accounting Research, 39(3), 417-434.

Aylward, A., \& Glen, J. (2000). Some international evidence on stock prices as leading indicators of economic activity. Applied Financial Economics, 10, 1-14.

Bagnoli, M., \& Watts, S. G. (2010). Oligopoly, disclosure, and earnings management. The Accounting Review, 85(4); 1191-1214.
Ball, R. (2006). International Financial Reporting Standards (IFRS) pros and cons for investors. Accounting and Business Research, 5-27.

Barth, M. E., Landsman, W. R., Lang, M., \& Williams, C. (2012). Are IFRS-based and US GAAP-based accounting amounts comparable? Journal of Accounting and Economics, 54(1), 68-93.

Barth, M. E., Landsman, W. R., Lang, M. H., \& Williams, C. D. (2013). Effects on comparability and capital markets benefits of voluntary adoption of IFRS by US firms: insights from voluntary adoption of IFRS by non-US firms (working paper). Stanford, CA: Rock Center for Corporate Governance.

Beaver, H., Lambert, R. A., \& Ryan, S. G. (1987). The information content of security prices: a second look. Journal of Accounting and Economics, 9, 139-157.

Brochet, F., Jagolinzer, A. D., \& Riedl; E. J. (2013). Mandatory IFRS adoption and financial statement comparability. Contemporary Accounting Research, 30(4), 1373-1400. 
Brugni, T. V., Fávero, L. P. L., Flores, E. S., Beiruth, A. X. (2015). O vetor de causalidade entre o lucro contábil e o preço das ações: existem incentivos para informação contábil seguir o preço no Brasil? Revista Contabilidade Vista \& Revista, 26(1), 79-103.

Carvalho, L. N., \& Salotti, B. M. (2013). Adoption of IFRS in Brazil and the consequences to accounting education. Issues in Accounting Education, 28(2), 235-242. •

Cascino, S., \& Gassen, J. (2012). What drives the comparability effect of mandatory IFRS adoption? (working paper). Rochester, NY: Social Science Research Network.

Cole, V., Branson, J., \& Breesch, D. (2012). The uniformity: flexibility dilemma when comparing financial statements - views of auditors, analysts and other users. International Journal of Accounting \& Information Management, 20(2), 114-141.

Collins, D. L., Pasewark, W. R., \& Riley, M. E. (2012). Financial reporting outcomes under rules-based and principles-based accounting standards. Accounting Horizons, 26(4), 681-705.

Costa, F, M., Reis, D. J. S., \& Teixëira, A. M. C. (2012). Implicações de crises econômicas na relevância da informação contábil das companhias brasileiras. REPeC, 6(2), 141-153.

D'Arcy, A. (2000, janeiro): The degree of determination of national accounting system: an empirical investigation. Schmalenbach Business Review, 52, 45-67.

Datta, S., Iskandar-Datta, M., \& Singh, V. (2013). Product market power, industry structure, and corporate earnings management. Journal of Banking \& Finance, 37(8), 3273-3285.

Dechow, P., Ge, W., \& Schrand, C. (2010). Understanding earnings quality: a review of the proxies, their determinants and their consequences. Journal of Accounting and Economics, 50(2-3), $344-401$

DeFond, M., Hu, X., Hung, M., \& Li, S. (2011). The impact of mandatory IFRS adoption on foreign mutual fund ownership: the role of comparability. Journal of Accounting and Economics, 51(3), 240-258.

DeFranco, G., Kothari, S. P., \& Verdi, R. S. (2011). The benefits of financial statement comparability. Journal of Accounting Research, 49(4), 895-931.

Dhaliwal, D. S., Salamon, G. L., \& Smith, E. D. (1982). The effect of owner versus management control on the choice of the accounting methods. Journal of Accounting and Economics, 4, 41-53.

Dhaliwal, D., Subramanyam, K. R., \& Trezevant, R. (1999). Is comprehensive income superior to net income as a measure of firm performance? Journal of Accounting and Economics, 26(1-3), 43-67.

Donelson, D. C., McInnis, J. M., \& Mergenthaler, R. D. (2012). Rulesbased accounting standards and litigation. The Accounting Review, $87(4), 1247-1279$

Doyle, J., Ge, W., \& McVay, S. (2007). Determinants of weaknesses in internal control over financial reporting. Journal of Accounting and Economics, 44(1-2), 193-223

Dye, R. A. (1985). Strategic accounting choice and the effects of alternative financial reporting requirements. Journal of Accounting Research, 23(2), 544-575.

Dye, R. A., \& Verrecchia, R..(1995). Discretion vs. uniformity: choices among GAAP. The Accounting Review, 70(3), 389-415.

Fang, X., Li, Y., Xin, B., \& Zhang, W. J. (2012). Accounting comparability and loan contracting (working paper). Rochester, NY: Social Science Research Network

Fávero, L. P. (2015). Análise de dados: modelos de regressão com Excel, Stata e SPSS. Rio de Janeiro: Elsevier.

Financial Accounting Standards Board. (2002). Proposal for a principles-based approach to U.S. standard setting. Norwalk, CT: FASB.

Financial Accounting Standards Board. (2010, September). Statement of financial accounting concepts no. 8: conceptual framework for financial reporting. Norwalk, CT: FASB.

Francis, J., Hanna, J. D., \& Vincent, L. (1996). Causes and effects of discretionary asset write-offs. Journal of Accounting Research, 34(Suplemento), 117-134

Fundação Instituto de Pesquisas Contábeis, Atuariais e Financeiras, \& Ernst \& Young. (2013). Análise sobre o IFRS no Brasil (3a. ed.). São Paulo: Ernst \& Young.

Hadi, A. S. (1992). Identifying multiple outliers in multivariate data. Journal of the Royal Statistical Society, 54(3), 761-771.

Himmelberg, C. P., Hubbard, R. G., \& Palia, D. (1999). Understanding the determinants of managerial ownership and the link between ownership and performance. Journal of Financial Economics, 53(3), 353-384.
Holthausen, R. W. (2009). Accounting standards, financial reporting outcomes, and enforcement. Journal of Accounting Research, 47(2), 447-458.

Iatridis, G. (2010). International financial reporting standards and the quality of financial statement information. International Review of Financial Analysis, 19(3), 193-204.

International Accounting Standards Board. (2010). The conceptual framework for financial reporting. London: IASB

Ittner, C. D., Larcker, D. F., \& Rajan, M. V. (1997). The choice of performance measures in annual bonus contracts. The Accounting Review, 72(2), 231-255.

Jamal, K., \& Tan, H. (2010). Joint effects of principles-based versus rules-based standards and auditor type in constraining financial managers' aggressive reporting. The Accounting Review, 85(4), $1325-1346$.

Kim, S., Kraft, P., \& Ryan, S. G. (2013). Financial statement comparability and credit risk (working paper). New York: Stern School of Business.

Kohlbeck, M., \& Warfield, T. (2010). Accounting standard attributes and accounting quality: discussion and analysis. Research in Accounting Regulation, 22(2), 59-70.

Kothari, S. P., Ramanna, K., \& Skinner, D. J. (2010). Implications for GAAP from an analysis of positive research in accounting. Journal of Accounting and Economics, 50(2-3), 246-286.

Lafond, R., \& Roychowdhury, S. (2008). Managerial ownership and accounting conservatism. Journal of Accounting Research, 46(1), $101-135$

Lang, M. H., Maffett, M., \& Owens, E. (2010). Earnings comovement and accounting comparability: the effects of mandatory IFRS adoption (working paper). Rochester, NY: Social Science Research Network.

Lawrence, A., Minutti-Meza, M.; \& Zhang, P. (2011). Can big 4 versus non-big 4 differences in audit-quality proxies be attributed to client characteristics? The Accounting Review, 86(1), 259-286.

Lee, C.-W. J., Li, L. Y., \& Yue, H. (2006, May). Performance, growth and earnings management. Review of Accounting Studies, 11, 305-334.

Lilien, S., \& Pastena, V. (1981). Intramethod comparability: the case of the oil and gas industry. The Accounting Review, 56(3), 690-703.

Lopes, A. B. (2011). Teaching IFRS in Brazil: news from the front. Accounting Education, 20(4), 1-9.

Lopes, A. B., \& Walker, M. (2010). Firm-level incentives and the informativeness of accounting reports: an experiment in Brazil (working paper). Rochester, NY: Social Science Research Network.

Madsen, P. E. (2011). How standardized is accounting? The Accounting Review, 86(5), 1679-1708.

McVay, S., Nagar, V., \& Tang, V. W. (2006). Trading incentives to meet the analyst forecast. Review of Accounting Studies, 11(4), 575-598.

Mergenthaler, R. D. (2009). Principles-based versus rules-based standards and earnings management (working paper). Iowa City, IA: University of Iowa.

Merino, B. D., \& Coe, T. L. (1978, agosto). Uniformity in accounting: a historical perspective. The Journal of Accountancy, 62-69.

Neel, M. (2013). Accounting comparability and economic outcomes of mandatory IFRS Adoption (working paper). Rochester, NY: Social Science Research Network.

Nelson, M. W. (2003). Behavioral evidence on the effects of principles and rules-based standards: Accounting Horizons, 17(1), 91-104

Peterson, K., Schmardebeck, R., \& Wilks, J. T. (2012). Accounting comparability and earnings attributes (working paper). Rochester, NY: Social Science Research Network.

Psaros, J. I. M., \& Trotman, K. E. N. T. (2004). The impact of the type of accounting standards on preparers' judgments. Abacus, 40(1) 76-93.

Ribeiro, A. M. (2014). Poder discricionário do gestor e comparabilidade dos relatórios financeiros: uma análise dos efeitos da convergềncia do Brasil às IFRS (Ph.D. Thesis). Faculdade de Economia, Administração e Contabilidade, Universidade de São Paulo, São Paulo.

Ryan, S. G. (1995). A model of accrual measurement with implications for the evolution of the book-to-market ratio. Journal of Accounting Research, 33(1), 95-112.

Schipper, K. (2003). Principles-based accounting standards. Accounting Horizons, 17(1), 61-72.

Securities and Exchange Commission. (2003). Study pursuant to Section 108 (d) of the Sarbanes-Oxley Act of 2002 on the adoption by the United States financial reporting system of a principles-based accounting system. Retrieved from http://www. 
sec.gov/news/studies/principlesbasedstand.htm

Silva, R. L. M. (2013). Adoção completa das IFRS no Brasil: qualidade das demonstrações contábeis e o custo de capital próprio (Ph.D. Thesis): Faculdaide de Economia, Administraçấo e Contabilidade, Universidade de São Paulo, São Paulo.

Simmons, J. (1967, outubro). A concept of comparability in financial reporting. The Accounting Review, 680 692 .

Sohn, B. C. (2011). The effect of accounting comparability on earnings management (working paper). Hong Kong: City University of Hong Kong.

Stolowy, H., \& Ding, Y: (2003). Regulatory flexibility and management opportunism in the choice of alternative accounting standards: an illustration based on large French groups. The International Journal of Accounting, 38, 195-213.

Sunder, S. (2009). IFRS and the accounting consensus. Accounting Horizons, 23(1), 101-111.

Taplin, R. H. (2010). Statistical inference using the T index to quantify the level of comparability between accounts. Accounting and Business Research, 40(1), 75-103.
Tweedie, S. D. (2007). Can global standards be principle based? The Journal of Applied Research in Accounting and Finance, 2(1), 3-8.

Verrecchia, R. E., \& Weber, J. (2006). Redacted disclosure. Journal of " Accounting Research, 44(4), 791-814.

Watts, R. L., \& Zimmerman, J. L. (1986). Positive accounting theory. New Jerșey: Prentice Hall Career \& Technology.

Webster, E., \& Thornton, D. B. (2004). Earnings quality under rules vs. principles-based accounting standards: a test of the Skinner hypothesis (working paper). Kingston, ON: Queen's University. School of Business.

Wooldridge, J. M. (2013). Introductory econometrics: a modern approach (5a. ed.). Mason, $\mathrm{OH}$ : South-Western Cengage Learning.

Yip, R. W. Y., \& Young, D. (2012). Does mandatory IFRS adoption improve information comparability? The Accounting Review, $87(5), 1767-1789$.

Young, S., \&.Yang, J. (2011). Stock repurchase and executive compensation contract design: the role of earnings per share performance conditions. The Accounting Review, 86(2), 703-733.

\section{Correspondence Address:}

\section{Alex Mussoi Ribeiro}

Universidade Federal de Santa Catarina, Centro Socioeconômico - Bloco F, Departamento de Ciências Contábeis

R. Eng. Agronômico Andrei Cristian Ferreira, s/n - CEP: 88040-970

Campus Universitário Trindade - Florianópolis - SC

Email: areksu@terra.com.br 